\title{
Theophanes, Potamon and Mytilene’s Freedom
}

\author{
Marcin N. Pawlak \\ iD http:/orcid.org/0000-0002-2841-469X \\ Nicolaus Copernicus University, Toruń
}

\begin{abstract}
Theophanes and Potamon of Mytilene, two Greek euergetes who sought to serve their home polis in a rapidly changing political landscape of the late Roman Republic and early Principate, took an active interest in the politics of the day and sought to lobby Roman elites on Mytilene's behalf. Theophanes befriended and advised Pompey, contributing to Pompey's decision to pardon and liberate Mytilene after the city's ignominious participation in the Asiatic Vespers, whereas Potamon served as Mytilene's ambassador in Rome, adroitly championing its city's interests. Two politicians bettered Mytilene's political status in the tumultuous period of transformation from a republic to an autocracy and ensured that the city maintained its freedom until the times of the Flavians.
\end{abstract}

Keywords: Theophanes of Mytilene, Potamon of Mytilene, Mytilene, Roman Greece.

Mytilene's relations with Rome deteriorated in the 1st century BC when the city sided with Mithridates during his first war against Rome: after the conflict, Mytilene, forcibly incorporated into the province of Asia, lost much of its former independence, only to regain it twenty years later, its change of fortune attributable to efforts of Mytilene's two outstanding citizens, Theophanes and Potamon. The pair acted as euergetai, highstatus and wealthy individuals distributing part of their wealth to their communities in the Hellenistic and Roman eras. Exerting considerable political and personal influence, Theophanes, a close friend of Pompey, managed to talk Pompey into granting Mytilene special privileges, whereas Potamon served as Mytilene's ambassador in Rome, adroitly championing its city's interests. Theophanes and Potamon guided and supported Mytilene as Rome underwent a tumultuous period of transformation from a republic to an autocracy, ensuring that Mytilene would relish its hard-won freedom until the times of the Flavians. Their backing enabled Mytilene to get into the international politics: the city maintained its newly elevated status and periodically received affirmations of its privileges from successive Roman rulers and the Senate. The following article examines 
the influence of Theophanes and Potamon on Mytilene's political standing in the late Republican and early Imperial periods.

Mytilene, a city on the island of Lesbos, maintained a complicated and often tumultuous relationship with Rome in the late Hellenistic and early Roman periods. At the beginning, Mytilene and Rome apparently remained at peace. The fist surviving mention of a diplomatic relationship between Mytilene and Rome concerns the period when Rome waged war against Antiochus II. Supporting the Roman side, Mytilene lent Rome its navy and opened its ports to the Roman naval forces. ${ }^{1}$ No testimonies survive on the post-war international relations between Rome and the Lesbian polis. Concerning domestic matters on Lesbos, four local poleis (Mytilene, Methymna, Eresos and Antissa) are known to have created a league (koinon), whose aim was to ensure the safety of the allied cities and to pursue a joint foreign policy ${ }^{2}$ however, later events suggest that the allied cities pursued independent international policies, with Rome elevating Methymna at the expense of other poleis. During the Third Macedonian War, the city of Antissa backed Perseus; Rome retaliated by destroying Antissa and displacing its citizens to Methymna in $167 \mathrm{BC}$, a decision that clearly favoured Methymna. ${ }^{3}$ We do not know whether Eresos and Mytilene tried to protest this decision; we do know that, from that point onward, Rome supported Methymna and eventually signed an alliance with this polis (ca 129 BC). Rome's only formal ally on Lesbos, Methymna enjoyed the status of a city which was immunes ac libera, whereas other Lesbian cities might have had the same status but they were not formally allied with Rome. ${ }^{4}$ Rome's favouritism towards Methymna, together with other factors unknown to us, might have had an impact on Methymna's position during the war between Rome and the king of Pontus, Mithridates; the same war marked the deterioration of a relationship between Mytilene and Rome.

During the First Mithridatic War (88-85 BC), Mytilene followed the example of many neighbouring poleis in the eastern Mediterranean: initially neutral, the city decided to support Mithridates and in due course paid the consequences. In late 89 or early $88 \mathrm{BC}$, Mithridates convinced friends and allies in Anatolia to orchestrate the assassination of all Roman and Italian citizens in Asia Minor during the so-called Asiatic Vespers. Manius Aquilius, a Roman general, fled the carnage in Pergamon and initially found refuge in Mytilene; nevertheless, the city subsequently pledged its allegiance to Mithridates and returned Manius Aquilius and other Romans to Pergamon, where they were cruelly slain. ${ }^{5}$ The decision incurred the lasting enmity between Rome and Mytilene, still detectable in Velleius Paterculus' account dated to the 1 st century CE. ${ }^{6}$ Undoubtedly fearing Rome's revenge, Mytilene clung to Mithridates long after the war had ended and the king had returned to Pontus; initially besieged by Lucullus, the city ultimately

Polib. 35.45. The present paper was prepared thanks to the grant from the National Science Centre: UMO-2012/7/B/HS3/03455.

2 IG XII, Suppl. 120; Labarre 1996a, 75-76.

3 Liv. 45.31.13; Accame 1946, 109; Labarre 1996a, 82.

4 Labarre 1996a, 85.

5 Diod. Sic. 37.27; App. Mith. 12.3.21.

6 Vell. Pat. 2.18. 
fell to Minucius Thermus. ${ }^{7}$ The conquered Mytilene lost its status of a free city (civitas libera), became a part of the province of Asia and saw its lands incorporated into the ager publicus.

\section{Theophanes}

Very little information survives about what happened in underprivileged Mytilene after 88 BC: the city reappears in our sources in $62 \mathrm{BC}$, when Pompey, returning from his expedition to the East, is recorded to have visited Mytilene with his friend, Theophanes the Mytilenean. Plutarch relays that the general witnessed the traditional contest of the poets who praised Pompey's exploits; the general subsequently gave back the city its freedom, reportedly for Theophanes' sake. ${ }^{8}$ Velleius Paterculus, Plutarch's predecessor, corroborates his account, naming Theophanes as the person to whom Mytilene owned its freedom. ${ }^{9}$

Theophanes of Mytilene, mentioned in Velleius Paterculus and Plutarch's accounts, appeared frequently in the works of ancient writers and in epigraphic material; although we cannot date every event of his life, we possess enough information to trace his career in broad strokes. Born of otherwise unknown Hiroitas (or Hieroitas), Theophanes must have belonged to a local elite family on Lesbos. Theophanes' youth coincided with Mytilene's economic and political downturn: having lost its freedom, the city was being punished for its anti-Roman position during the First Mithridatic War, and, like many cities in the East, suffered from the mistreatment at the hands of Roman publicans. The turning point that defined Theophanes' life happened when he met and befriended Pompey - possibly in $67 \mathrm{BC}$, when Pompey, given broad powers, came to the eastern Mediterranean to fight pirates. Mytilene, conveniently located on the eastern coast of Lesbos, most likely became Pompey's naval base; governing his affairs from this polis, Pompey met and turned his attention to the local statesman, Theophanes.

Theophanes' exploits at Pompey's side feature most prominently in Strabo's work: ${ }^{10}$ the author emphasised that Theophanes actively participated in Mytilene's political life and hence attracted Pompey's attention. Strabo indicates that Pompey aided Theophanes in some unspecified public works in Mytilene, with the city's welfare owing much to their combined efforts. Significantly, Strabo stressed that Pompey respected Theophanes for his political ability and not for his literary talent, on which Theophanes' later fame came to rest. In that context, Strabo's reference to Theophanes the historian probably capitalised on Theophanes' subsequent literary fame: readers would more readily identify Theophanes because Strabo stressed the profession Theophanes was best known for. ${ }^{11}$

7 Livy, per. 89; Plut. Luc. 4. 2-4; Suet. Caes. 2; App. Mitr. 12.8.25. Young Julius Caesar took part in the siege of the city.

8 Plut. Pomp. 42.

9 Vell. Pat. 2.18.

10 Strabo 13.2.3.

11 Glucker 1978, 23. 
Strabo did not mention where and in what circumstances Pompey and Theophanes first met, but the context of his narrative ostensibly implies that the meeting happened in Mytilene at the time when Pompey stayed there, with Pompey's only recorded visit there dated to 62 BC. Nevertheless, as we have mentioned above, Theophanes appears to have already been close to the general at that point, since he used his connection to Pompey to regain freedom for his home city. Therefore, we should follow Strabo's account and assume that Theophanes and Pompey met a few years prior to $62 \mathrm{BC}$ and that Theophanes accompanied the general in his various exploits. The most likely interpretation dates their first meeting to $67 \mathrm{BC}$, when Pompey set out on his expedition to the East. ${ }^{12}$

It follows from another fragment of Strabo's work that Theophanes accompanied Pompey during his campaign in the East as an advisor and guide, taking an active part in the war. Relevantly, although Pompey was initially tasked only with eliminating pirates, in $66 \mathrm{BC}$ he was granted even greater powers, becoming the commander in the war against Mithridates. ${ }^{13}$ Pompey, like other Roman generals active in the East, allowed Greeks into his inner circle, his guides in a world very foreign to the Romans. ${ }^{14}$ Theophanes, an active statesman, probably had good knowledge of the political situation in the eastern Mediterranean and advised Pompey on local matters. Granted, Theophanes' literary talent might have also endeared him to Pompey, but it was his political acumen that made Theophanes indispensable. What is certain is that, during the war in the East, Theophanes faithfully recorded Pompey's exploits, becoming, as Cicero described him, a scriptor rerum Pompeii. Theophanes' work, surviving only as an untitled bundle of fragments, must have been well known already in $62 \mathrm{BC}$, with Cicero referring to it in his speech Pro Archia, dated to this year. ${ }^{15}$

According to Strabo, Theophanes fought at Pompey's side and impressed him so much that the general granted him Roman citizenship in the presence of the army, who acclaimed the decision. ${ }^{16}$ Another writer mentioning Theophanes' distinction, Cicero, narrated that Pompey honoured Theophanes in this manner in reward for him recording Pompey's campaign in the East. Accordingly, Cicero appears to have deemphasised Theophanes' advisory acumen in this passage, although he praised it at length in his letters to Atticus (see below). ${ }^{17}$ Valerius Maximus confirms Cicero's words on the circumstances of Theophanes' distinction, adding that Theophanes was honoured during an assembly of Pompey's soldiers and the general gave a speech in which he justified his decision. ${ }^{18}$ Theophanes probably received Roman citizenship towards the end of the campaign, or perhaps even after it ended, i.e. in the summer of 62 BC. From this point forward, Theophanes used the name Gnaeus Pompeius Theophanes.

12 Anderson 1963, 22; Gold 1985, 319. Sevin (1743), one of Theophanes' first modern biographers, put forward a different theory. He concluded that Pompey's acquaintance with Theophanes started in the 80s BC, when, during the First Mithridatic War, young Theophanes supposedly left Asia and headed to Italy, where he met Pompey. However, there are no grounds to indicate that Theophanes met Pompey so early.

13 Strabo 11.5.1.

14 Bowersock 1965, 2-4.

15 Cic. Arch. 24.

16 Cic. Arch. 24: in contione militum donavit; Strabo 11.5.1; Santangelo 2007, 40.

17 Rawson 1985, 99; Ferrary 1988, 611-612.

18 Valerius Maximus 8.14.3: beneficium per se amplum accurata etiam et testats oratione prosecutus. 
More thought-provoking (although semi-anecdotal) information about Theophanes' exploits at Pompey's side surfaces in Plutarch's works. One anecdote concerns Mithridates' personal notes, supposedly found in a fortress in Armenia that surrendered to the Romans, with both Pompey and Theophanes very interested in their content. Allegedly, the notes named and contained the address of one Rutilius Rufus, a Roman exile living in the East, who ostensibly incited Mithridates to murder all the Romans in Asia during the Asiatic Vespers. According to Plutarch, many people believed that Theophanes himself had written the address: supposedly, Theophanes aimed both to ingratiate himself with Pompey for denouncing another enemy of Rome and to exact revenge on Pompey's behalf, since Rutilius Rufus' father had presented Pompey in a very unfavourable light in his historical work. ${ }^{19}$ The second of the anecdotes recorded by Plutarch, reportedly told by Timagenes, concerned Ptolemy Auletes, who had left Egypt and later wanted to recapture the throne. Timagenes believed that it was Theophanes who talked Ptolemy into leaving Egypt in order to give Pompey a new command. ${ }^{20}$

Theophanes and Pompey remained friends long after Pompey's return to Rome, with their friendship recorded in Cicero's letters. Throughout the 50s BC, Theophanes served as one of the general's advisors and frequently found himself entangled in the Roman political life, with Cicero's correspondence regularly referring to Theophanes from $59 \mathrm{BC}$ onward. In a letter from 59 BC, Cicero, who had been offered by Caesar and Pompey to go on a diplomatic mission to Egypt, asked his friend Atticus to discuss the matter with Theophanes. ${ }^{21} \mathrm{~A}$ few weeks later, Cicero again wrote Atticus a letter asking him to talk to Theophanes and to find out what his friend Pompey's plans towards him were. ${ }^{22}$ Cicero's letters demonstrate that Theophanes maintained close relations with Pompey and could easily find out about his patron's private opinions. Theophanes is mentioned in Cicero's letter from 58 BC, although the author's reticence makes it difficult to ascertain what he was referring to in his letter. ${ }^{23}$ Subsequently, Cicero ceased to refer to Theophanes in his letters, only to mention him again in $51 \mathrm{BC}$. In the summer of this year, Cicero wrote Atticus a missive to inform him that he had learnt of Pompey's plans to go to Spain; Cicero apparently did not approve of these plans and attempted to influence Pompey through Theophanes, adding that, in his opinion, no one had as much influence over Pompey as Theophanes. ${ }^{24}$ Theophanes' name appeared again in Cicero's letters from 50 and $49 \mathrm{BC},{ }^{25}$ and then, for the final time, in a letter from $44 \mathrm{BC}$, in which Cicero informed Atticus that he had received a letter from Theophanes asking him for a meeting to discuss matters of possible interest to Cicero. ${ }^{26}$ The letters of the Roman orator showcase that Theophanes remained one of Pompey's most trusted advisors and confidantes and, as such, he accumulated a great deal of political capital in Rome.

\footnotetext{
19 Plut. Pomp. 37.

20 Plut. Pomp. 49.

21 Cic. Att. 2.5.1.

Cic. Att. 2.17.3.

Cic. Att. 8.12.5; Anderson 1963, 38.

Cic. Att. 5.11.3.

Cic. Att. 7.7.6; 9.1.3.

Cic. Att. 15.12.1.
} 
Taking into consideration Theophanes' career and his influence on Pompey, we can now reconsider Theophanes' contribution to Mytilene regaining freedom in $62 \mathrm{BC}$. As I showed above, Velleius Paterculus and Plutarch agree that Pompey returned Mytilene its freedom mainly for the sake of his friendship with its citizen, Theophanes. Certainly, Mytilene itself also strove to win Pompey's favour: the polis organised a contest of the poets in Pompey's honour and celebrated his exploits in the East. From the 19th century onwards, historians uncritically accepted Plutarch and Velleius Paterculus' accounts and, for all intents and purposes, did not even endeavour to advance other explanations for Pompey's partiality towards Mytilene. ${ }^{27}$ Yet, it is difficult to believe that Pompey would so eagerly privilege a city that had not so long ago betrayed Rome (as Velleius Paterculus pointedly reminds us) solely to reward his friend Theophanes. In 1995, V. Anastasiadis ${ }^{28}$ attempted to identify other reasons that might have motivated Pompey's behaviour; in her opinion, Pompey deliberately chose disgraced Mytilene to flaunt his clementia and to win the loyalty of the Greeks. Granted, Pompey remained aware that this controversial deed would spark public outrage in Rome, but, at least in this case, the opinion of the Greeks mattered more to him than that of the Romans. Pompey's actions won him Mytilene's long-lasting gratitude: the city hosted his wife and son during his war against Caesar and Pompey's son Sextus found temporary refuge on the island in 36 BC.

Should we consider the entirety of Pompey's actions in the East, his treatment of Mytilene appears neither exceptional nor unusual. Pompey intended to achieve two aims: first, to secure Rome's interests in the East; second, to do so in a way that would benefit — or at least not antagonise - the communities of the eastern Mediterranean. ${ }^{29}$ Plutarch, writing on Mytilene regaining its freedom, also enumerated Pompey's benefactions towards Rhodes and Athens; likewise, the Roman general showed great generosity to Ilion, Miletus and Miletopolis. ${ }^{30}$ Pompey believed that winning divided loyalties of independent cities in the eastern Mediterranean would be the best safeguard against dissenters wishing to arouse anti-Roman sentiments in the East. ${ }^{31}$ His gesture of goodwill towards Mytilene closely aligned with his international policy in the region.

V. Anastasiadis pointed out yet another factor that might have obscured Pompey's primary motivation for liberating Mytilene. The accounts of Velleius Paterculus and Plutarch postdate Mytilene's liberation by Pompey. Plutarch's biography of Pompey perceptibly draws from Theophanes' lost work, although it remains disputed whether Theophanes described the events of 62 BC. ${ }^{32}$ Nevertheless, a subset of scholars assumes that Theophanes continued his narration up until the year $59 \mathrm{BC} .{ }^{33}$ Should we accept this interpretation, we must also assume that Theophanes embellished or highlighted his role in securing freedom for the city, with Theophanes' skewed narration later uncritically

27 Cichorius 1888, 7; Chapot 1904, 107; Laqueur 1934, 2093; Leach 1978, 101; Seager 1979, 52; Green 1984, 19; Sherwin-White 1984, 254; Gold 1985, 324.

28 Anastasiadis 1995: passim.

29 App. Mithr. 115; Cassius Dio 37.20.

30 Anastasiadis 1995, 7-8.

31 On the topic of Roman generals who gave freedom to cities in the 1st century BC and their motives, see Jones 1971, 62-63.

32 Rawson 1985, 108.

33 Laqueur 1934, 2125-2127. 
copied by Plutarch. It might have not been so for Velleius Paterculus, whose text decried Mytilene's betrayal and criticised both Pompey and Theophanes. Indeed, Velleius' critical attitude towards Pompey and Theophanes might have stirred up additional hatred against Theophanes' descendants in AD 33, leading them into exile or even driving them to suicide. ${ }^{34}$ Theophanes' descendants faced persecution mostly because they associated with Sejanus' circle, but their family history and Mytilenean extraction did not endear them to the Romans. Significantly, Theophanes' posthumous deification might have also counted against him. The popular opinion held that Pompey abused his unlimited powers in the East, showed favouritism to his friend Theophanes and unjustly honoured a city that had formerly betrayed Rome in the most egregious manner, with Theophanes' descendants being ostracised for alleged sins of their father.

Bearing in mind that Mytilene's liberation aligned with Pompey's general policy in the East, we cannot deny that it was Theophanes who probably encouraged Pompey to visit Lesbos, familiarised the Roman general with the local situation and who probably requested that Pompey give the city its freedom. Therefore, we should neither underestimate or overestimate his role in motivating Pompey's gesture. Had he not met Theophanes, Pompey would have most probably ignored Mytilene altogether; accordingly, it appears that Anastasiadis' interpretation skews the available evidence to obfuscate Theophanes' role in Mytilene's liberation and thus cannot be uncritically accepted. ${ }^{35}$

As a result of Theophanes' intercession with Pompey, in 62 BC Mytilene became a civitas libera et immunis, its status approved three years later by the lex Iulia de actis Pompei. Some surviving evidence indicates that Pompey continued to take an interest in Mytilene's affairs even after 62 BC-or, more accurately, the Mytileneans never allowed Pompey to forget about them. In $55 \mathrm{BC}$, the senate, presided over by Pompey, issued a senatus consultum that granted Mytilene cattle grazing rights on an as-yet unidentified land and publicly reaffirmed that Mytilene' lands were exempt from the publicans' activity. ${ }^{36}$ The need to reaffirm the exemption showcases that the publicans operating in the East violated Mytilene's status as a free city after $62 \mathrm{BC}$, most probably by collecting taxes from Mytilene's domains in Asia Minor. In the three-year interval between Pompey's liberation (62 BC) and its approval by the senate (59 BC), publicans exploited the city's uncertain legal status to farm taxes on its lands. ${ }^{37}$ In response to publicans' abuse, Mytilene's authorities decided to send envoys to address the Roman senate, although probably not directly. In $55 \mathrm{BC}$, Pompey held the office of consul for the second time and it was he whom the Mytilenean ambassadors approached; they most likely reached the general through Theophanes, who was staying in Rome at the time. Thanks to the intervention of their influential compatriot, the ambassadors met Pompey and persuaded him to champion their cause: Pompey called the senate and ensured that it would pass a decree that would reaffirm Mytilene's rights. After ten years, in 45 BC, the senate passed yet another decree that renewed the bonds of friendship and alliance

34 Buraselis 2001, 61-67.

35 Labarre 1996a: passim, who strongly argued against Anastasiadis' opinions.

36 IG XII, 11; Sherk 1963b, 217-230; Sherk 1969, 143-145, no. 25.

37 Labarre 1996b, 50-51. For examples of other free cities which were harassed by the publicans, see Sherk 1963b, 229. 
between Rome and Mytilene and mentioned additional privileges given to the city, most probably referring to the senatum consultum ultimum of $55 \mathrm{BC} .^{38}$

Grateful for its regained freedom, Mytilene repaid the man whose intervention had ensured it. An inscription found on the Mytilenean acropolis immortalised Theophanes' full Roman name and lauded him as the city's saviour and benefactor, ${ }^{39}$ with the inscription's text dated to the period immediately following the city's liberation. ${ }^{40}$ More information about Theophanes' merits can be gleaned from the text of a dedication placed on the base of Theophanes' statue, originally erected in Mytilene and subsequently transported to Constantinople to adorn the new capital city. ${ }^{41}$ The dedication text lauded Theophanes for restoring the city's freedom and its territory from the hands of the Romans and for restoring local temples. Both L. Robert (the first publisher of this inscription) and G. Labarre proposed to date the inscription to 62 or 61 BC. Nevertheless, the inscription could have been carved later, perhaps even post-55 BC, to commemorate Theophanes' contribution to defending Mytilene's lands against the publicans. ${ }^{42}$ Whichever interpretation we follow, Mytilene certainly wanted to reward its benefactor generously. The memory of Theophanes' accomplishments lived on in Mytilene long after his death. Mytilene worshipped Theophanes as a theos, as evidenced by surviving inscription dedicated to Pompey, Theophanes and Potamon. The dedication to Theophanes identifies him with Zeus Eleutherios, demonstrating that Mytilene decided to posthumously deify Theophanes in appreciation of his achievements that led to the city regaining its freedom. ${ }^{43}$ Moreover, the likenesses of deified Theophanes and his wife Archidamis appear on Augustan and Tiberian coins in Mytilene, being labelled Theophanes Theos and Archedamis Thea. ${ }^{44}$

As expressed by the abovementioned inscription, Mytilene also celebrated Pompey for his liberation of the city; the Roman general could rely on the Mytileneans' loyalty until the end of his days and entrusted them with lives of his wife Cornelia and his son when he became embroiled in a war against Caesar. After his defeat at Pharsalos, Pompey arrived on Lesbos to collect his family and continue their escape together, against the wishes of the Mytileneans, who invited him to stay in their city. Before his departure, Pompey advised the Mytileneans not to fear Caesar, whom he depicted as a just and kind man, and to surrender to him in hope he will spare their city. Arriving in Attaleia in Pamphylia, Pompey conferred with his advisors as to where travel next. Pompey intended to take refuge with the Parthians and attack Caesar again after assembling a larger military force. However, Theophanes decried Pompey's idea as madness and suggested fleeing to Egypt instead, with his opinion ultimately prevailing. ${ }^{45}$

\footnotetext{
38 Sherk 1963b, 230.

39 IG XII, 2.150.

40 Robert 1969, 49; Rowe 2002, 125.

41 Robert 1969, 52-53; Feissel 2012, 3.

42 Robert 1969, 63; Labarre 1996a, 275-276 (no. 18).

43 Laqueur 1934, 2093; Buraselis 2001, 64; Salzmann 1985, 251-252; Robert 1969, 49.

44 Salzmann 1985, 254-260; Buraselis 2001, 64-66.

45 Vell. Pat. 2.53.2; Plut. Pomp. 66, 74, 76, 78.
} 


\section{Potamon}

Presented above is the previously mentioned inscription specifying that the Mytileneans worshipped Theophanes as a theos; relevantly, the inscription celebrates two other individuals: Pompey - the victorious general, benefactor, saviour and founder - and Potamon, son of Lesbonax, a benefactor, saviour and founder of the city. A crucial piece of evidence, the inscription honours three men who made very valuable contributions to Mytilene: Pompey, who returned Mytilene's freedom; Theophanes, who successfully pleaded for the freedom to be restored; and Potamon, who succeeded in maintaining Mytilene's elevated status during a period of political upheaval that marked the transition from a republic to an autocracy.

Not unlike Theophanes, Potamon, a Mytilenian statesman and writer, befriended influential Romans to safeguard his city's interests. Although Potamon's literary fame did not equal Theophanes' renown, his political accomplishments rivalled those of his great predecessor. The city honoured Potamon by erecting a building (Potamoneion) on Mytilene's acropolis, on whose walls hung many copies of official documents giving evidence of Potamon's great works for Mytilene. ${ }^{46}$ The city also funded him celebratory statues, a marble throne, an altar and a plethora of inscriptions praising Potamon as Mytilene's euergetes and saviour. Since many of these objects survive to this day, we have access to a wealth of information concerning the career of Potamon, a citizen of a provincial city who promoted the interests of his homeland by befriending and lobbying influential Romans. ${ }^{47}$

Our information on Potamon reveals little about his early life. Potamon's father, Lesbonax, had been a relatively well-known philosopher. ${ }^{48}$ Potamon distinguished himself as a rhetorician and a writer, his works including a treatise on the art of oration and encomia on Brutus, Caesar and Alexander the Great. None of these works have survived, but their titles are listed in the Byzantine encyclopaedia known as the Book of Suda ${ }^{49}$ Scholars estimate that Potamon lived between $75 \mathrm{BC}$ and $\mathrm{AD} 10$ (or, more likely, $\mathrm{AD} 15$ ). ${ }^{50}$ In $48 \mathrm{BC}$, Potamon first appears in the extant written records, a young Mytilenean so highly esteemed by his compatriots that they included him among envoys sent to Caesar. At that point in time, Mytilene's future seemed uncertain. The city, which had vociferously supported Pompey for fourteen years and gave him refuge after he lost the battle of Pharsalos, suddenly received the news about Caesar's impending arrival. The Mytileneans realised that Caesar certainly knew of their former allegiance to Pompey and could punish them for it. In late August $48 \mathrm{BC}$, Caesar stopped over in Sestos on the coast of the Hellespont. Appian relays that many Greek cities that had formerly supported

46 The name Potamoneion appears in the inscription $I G$ XII, 51. We do not know for how long the building had stood there before it was destroyed by an earthquake. Its stone remains were reused during the construction of a Turkish fortress on the acropolis. From 1884 onwards, new inscriptions surfaced, to be included in the corpus of inscriptions from Lesbos. Today, we know of approx. 60 fragmentary inscriptions which had originally been placed on the monument dedicated to Potamon.

47 IG XII, 2.272, Suppl. 44; IG XII, 2.159-163, Suppl. 43 and 45.

48 IG XII, 255; Suda L 307.

49 Suda L 307; Pearson 1960, 248-249; Bowersock 1969, 19.

50 Parker 1991, 118. 
Pompey sent ambassadors to Caesar and pledged their loyalty to him, with Appian stating that Caesar offered them his forgiveness. Although Appian only names the Ionians and the Aeolians, we have no reason to doubt that Mytilene also sent its envoys to placate the Roman general. One of documents originally placed on the walls of the Potamoneion recorded a letter from an unnamed Roman magistrate (a lacuna obscured his name), addressed to the boule and demos of Mytilene. Judging by the contents of the letter, many scholars argue that it was authored by Caesar. ${ }^{51}$ The sender of the message ensured the ambassadors that he would show goodwill towards Mytilene, both at present and in future. Relevantly to my analysis, the document names only five Mytilenean ambassadors to Caesar, but there could have been more of them, with Sherk arguing for as many as ten. Even if the surviving names of the ambassadors do not include Potamon, placing the said letter on a monument dedicated to him increases the likelihood that Potamon was included in the mission that travelled to meet Caesar and appeal for his city's interests. ${ }^{52}$

The letter discussed above proves beyond all doubt that Mytilene, like other Greek cities, immediately switched its allegiance from Pompey to victorious Caesar after the battle of Pharsalos, Pompey's encouragement to do so notwithstanding. The city passed a honorific decree for Caesar and sent envoys with its copy to the honorand..$^{53}$ The unusually large number of envoys Mytilene sent to Caesar showcases the great importance the city attached to this venture: normally, two or three ambassadors sufficed, whereas in special circumstances four or five were sent. As we have stated above, among the Mytilenean ambassadors sent to Caesar were included the rhetorician Potamon (probably) and the poet Krinagoras, son of Kallipos (undoubtedly). The reply letter attributed to Caesar is dated to the late summer of $48 \mathrm{BC}$ (September?), demonstrating that Mytilene sent the envoys soon after the battle of Pharsalos. The success of the diplomatic mission and Caesar's assurances of goodwill towards Mytilene must have relieved the city authorities for a short while; ${ }^{54}$ nevertheless, Caesar' vague promises could not satisfy the Mytileneans, who sought for other ways to assert and assure their independence.

Two other fragmentary inscriptions ascribed to Potamoneion indicate that Mytilene subsequently sent another mission to Caesar. The first inscription, a fragment from another letter from a Roman magistrate, ${ }^{55}$ appeared between two of Caesar's letters, suggesting that he may have also been its sender. The surviving fragments reveal that Caesar reassured the ambassadors of his goodwill, encouraged Mytilene to turn to him with various requests and promised that Rome did not intend to harm Mytilene. In other words, Mytilene belonged among Rome's amicii et socii, i.e. customary allies who did not sign a separate treaty with Rome ${ }^{56}$ As a formally independent municipality, Mytilene could offer military support to its ally and some evidence indicates that it did so after 48 BC. After the battle of Pharsalos, Caesar headed to Egypt; in June 47 BC, he set off to Cappadocia to fight the forces of Pharnaces II, whom he defeated in the battle of Zela. Another document placed on the walls of Potamon's monument indicates that

\footnotetext{
$51 \quad I G$ XII, 2.35; Sherk 1963a, 145-153.

52 Sherk 1963a, 148-149; Sherk 1969, 152-153.

53 Labarre 1996a, 110.

54 Dating of the letter: Sherk 1963a, 150; Dimopoulou-Piliouni 2010, 36-39.

$55 I G$ XII, 2.35 .

56 Accame 1946, 48-57; Badian 1958, 44.
} 
Mytilene sent forces to support Caesar during this campaign . The surviving fragment of this badly damaged inscription speaks of provisions, an ambassador and the war in Cappadocia. ${ }^{57}$ A. Dimopoulou-Piliouni combined data drawn from the two cited inscriptions and put forward an interesting hypothesis: less than a year after the Mytileneans first pledged their allegiance to Caesar, the city decided to improve its current legal status (amici) and ingratiate itself with Caesar by sending provisions for his army preparing for the war against Pharnaces. ${ }^{58}$ The historian identified the first inscription as a fragment of Caesar's letter thanking Mytilene for the food supply and the second inscription as a fragmentary inscription honouring Potamon, who supposedly approached Caesar again and presented Mytilene's proposal. Should we accept Dimopoulou-Piliouni's hypothesis, it would become clear that Mytilene strove continually to first establish and then strengthen its relations with Caesar. Potamon, in his capacity as Mytilene's ambassador, probably played a crucial role in all these diplomatic overtures.

Any agreement between Mytilene and Caesar, regardless of his dominant position and influence, required the senate's approval; therefore, Mytilene sent another group of envoys to Rome. What became of the diplomatic mission is revealed in Caesar's next letter, also containing the text of the senatus consultum..$^{59}$ Written at a point when Caesar was made dictator for the third time (i.e. between April 46 BC and January/February $45 \mathrm{BC}$ ), the letter mentioned the arrival of eight Mytilenean ambassadors, listing Potamon as the first. The ambassadors came to renew the treaty of friendship and alliance and to obtain a confirmation of the privileges they already enjoyed, directly petitioning the senate. Swayed by Caesar, the senate renewed Rome's friendship and alliance with Mytilene, although the text does not specify its terms; moreover, the senate also allowed the ambassadors to make a sacrifice on the Capitol. The Mytilenean ambassadors also requested, with the senate's approval, that their previously obtained privileges be inscribed on a bronze plaque - most likely, the said privileges granted thanks to Pompey's intervention. Well aware of the tumultuous political situation in Rome, the Mytilenean mission wanted their privileges recorded and displayed in public, believing that their public display would guarantee that they would not be withdrawn. Abiding by the senate's decision, Caesar could, if it were his wish, order the quaestor to provide the Mytilenean ambassadors with room and board. Additionally, at the request of the senators, Caesar himself made the decision to annul all exemptions from taxes in Mytilene; in other words, he decided that none of the Mytileneans should enjoy more privileges than the rest.

Thanks to the efforts of its ambassadors, Mytilene received everything it asked of the senate and it gained a new patron in Caesar. During the following three years, Caesar wrote the Mytileneans at least thrice; first two letters assured the citizens of Caesar's goodwill and the third conveyed the contents of the senatus consultum that would benefit Mytilene. The Mytileneans managed to escape the consequences of their former alliance with Pompey, partially due to Caesar's clemency, partially due to the diplomatic acumen and dedication of Mytilene's authorities. ${ }^{60}$ Mytilene rewarded Caesar's benevolence by

${ }^{57} I G \mathrm{XII}, 2.30[1]$.

58 Dimopoulou-Piliouni 2010, 41-42; see also Labarre 1996a, 96.

59 IG XII, 2.35, col. B.

60 Sherk 1969a, 154-155. 
honouring him with decrees that praised him as an euergetes and saviour of the city; ${ }^{61}$ not a long time afterwards, they also dedicated an altar to him. ${ }^{62}$ Having successfully championed Mytilene's interests in Rome, the ambassadors returned to Mytilene, save the poet Krinagoras who stayed behind for some time, joined the entourage of Octavian's sister Octavia and composed epigrams dedicated to members of the Roman elite. ${ }^{63}$ Meanwhile, Potamon returned to his homeland, where he continued to attend to political affairs and foster harmonious relations with Rome.

Despite the benefactions which they received from and thanks to Caesar, the Mytileneans never forgot about Pompey's benevolence. When the civil war broke out after Caesar's murder, Pompey's son Sextus Pompeius fled Sicily and sought refuge in the East; the citizens of Mytilene welcomed him enthusiastically and encouraged him to stay on the island. Sheltering a secret fugitive, however, did not mean that the city was ready to involve itself in the brewing civil war or that it made a political statement concerning its loyalties. As we know, Sextus left the island and was later murdered in Miletus. ${ }^{64} \mathrm{We}$ do not know what position Mytilene took during the war between Octavian and Mark Antony. The latter ordered his eastern allies to swear an oath of loyalty to him; he also recruited many mercenaries in the East, but we do not know whether any of them came from Mytilene. After the battle of Actium, adaptable Mytilene most probably quickly declared its loyalty to Octavian, from whom it received new privileges a few years later.

In $25 \mathrm{BC}$ another Mytilenean diplomatic mission went to sign a treaty with Rome; nevertheless, the envoys could not meet Augustus, who had resided in Spain since 26 BC. Augustus meant to wage a war against the Asturians and the Cantabrians, but, being of poor health, he passed the command to his legates and was recuperating in Tarragona. ${ }^{65}$ The ambassadors from Mytilene met Augustus' co-consul, Marcus Silanus, to whom they presented their expectations. Having received the news from Silanus, Augustus advised Silanus to set the terms that would both satisfy Mytilene and safeguard Rome's interests in the eastern Mediterranean. After concluding the treaty, the senate authorised Silanus to inform the Mytileneans of its contents and to inscribe its terms on a bronze plaque, to be publicly displayed in Rome. ${ }^{66}$

According to the treaty provisions, the Mytileneans pledged not to let any of Rome's enemies pass through their territories and not to start a war against Rome, its subjects and its allies. Rome's obligations mirrored those of Mytilene: Rome was not to let Mytilene's enemies pass through its territories and not to start a war against Mytilene, its subjects and its allies. Furthermore, if someone did start a war against Mytilene or Rome, the other party was to lend their support to the ally. The treaty also guaranteed the integrity of Mytilenean dominions both on Lesbos and in Asia Minor. The terms of the treaty classify it as belonging to foedera aequa, both parties formally equal in the light of its

$61 \quad I G$ XII, 2.151, 165, 166

62 IG XII, 2.26 .

63 In one of his epigrams, Anth. Pal. 7.628, Krinagoras mentioned the circumstances of the ambassadors' journey to Rome. During the mission, a boy named Eros (probably a son of one of the ambassadors) died and was buried on an islet near Ithaca.

64 App. BC 5.133; Cassius Dio 49.17.1.

65 Cassius Dio 53.25.2-8.

66 IG XII, 2.35; Arangio-Ruiz 1942, 125-130; Sherk 1969a, 155-156; Labarre 1996a, 102-103. 
provisions; even so, there was no doubt as to who the stronger party was. However, the Mytileneans must have found it crucial to sign a treaty with Rome which would confirm their independent status - an enclave among Roman domains that did not answer to the Roman governor of Asia. In fact, the governor could interfere in Mytilene's affairs only if the Mytileneans specifically asked him to do so. ${ }^{67}$

We do not know the names of the Mytilenean ambassadors who went to Rome in $25 \mathrm{BC}$; still, the placement of the inscription on a wall of the Potamoneion may indicate that Potamon participated in the mission. He might have also been joined by the poet Krinagoras, with some conjecturing that Krinagoras extended his trip to Rome to visit Augustus in Spain. Some of Krinagoras' poems preserved in the Palatine Anthology do mention Spain, but they cannot be dated and thus cannot support the hypothesis that the poet's visited the Iberian Peninsula in $25 \mathrm{BC}$ (and not before or after that date) ${ }^{68}$ However, another clue hints at the Mytilenean ambassadors travelling from Rome to Spain.

A few months before the ambassadors set off from Mytilene (probably in late 26 BC), the city issued a decree that bestowed special honours on Augustus, ${ }^{69}$ such as a theatrical contest in his honour. The tablets with a copy of the decree were to be displayed in a temple (under construction) in Pergamon and in Actium, Brundisium, Tarragona, Massalia and Antioch. The text of the decree was to be conveyed by the ambassadors who were setting off to Rome (their names have not survived). The ambassadors were to give Augustus a crown worth 2,000 drachmas and to thank the senate, Augustus' wife Julia Augusta, his sister, children, relatives and friends. Since Julia Augusta assumed this name only after Augustus' death in 14 AD, the surviving text of the decree is most likely a copy of the original document issued between AD 14 and AD 29, i.e. between Augustus and Livia's demises. As mentioned above, the text of the decree misses the names of the ambassadors; nevertheless, by the time of $\mathrm{C}$. Cichorius the mission was commonly believed to have included both Potamon and Krinagoras. Both Potamon and Krinagoras' participation in the mission appears more than probable: as two seasoned politicians and negotiators, the pair befriended many members of the Roman elites and accordingly had the best chance of furthering Mytilenean interests in Rome. Since a copy of the decree of 26 BC was to be displayed in Tarragona, the Mytileneans could have known that Augustus was staying in that town and directed their ambassadors to visit him there. By $26 \mathrm{BC}$, the imperial cult of Augustus was firmly established in Mytilene; Potamon became its priest, to be followed by other members of his family.

The evidence discussed above showcases that Potamon, a skilled rhetorician, participated in several diplomatic missions sent to Caesar and Augustus between $48 \mathrm{BC}$ and 25 BC, always striving to promote his city's interests abroad. Potamon's effectiveness and experience explain why Mytilene repeatedly entrusted him with the role of its ambassador and honoured him so lavishly, praising him as one of the best Mytilenean

67 Accame 1946, 94-99; Labarre 1996a, 103-104. According to Ferrary (1990, 233-234), the treaty in question resembles both a bilateral treaty on neutrality and a defensive alliance with a one-sided decision: the agreement guaranteed that Mytilene would enjoy certain privileges but at the same time stressed that the city, nominally independent, constitutes a part of the Imperium Romanum. See also Fournier 2010, 456-459.

68 One of Krinagoras' epigrams talks about one Seleucos, buried in distant Iberia: Anth. Pal. 7.376. Sherk 1969a, 156-157; Parker 1991, 117-118.

${ }^{69} I G$ XII, 2.58. Fishwick 1987, 171-172, 177, 496; Labarre 1996a, 285-287. 
statesmen in the period following 48 BC. Pompey's failure to seize the Roman empire forced Theophanes, Pompey's trusted advisor, to withdraw from politics, his place taken by unencumbered and adaptable Potamon, who made the most of the opportunity he was given. A seasoned ambassador, Potamon repeatedly visited Rome and was appreciated by the Romans for his skills. His position was such that he was encouraged to participate in something of a contest between rhetoricians for the position of Tiberius' tutor (Rome, ca $33 \mathrm{BC}$ ), ultimately won by Theodore of Gadara. ${ }^{70}$ Potamon's participation in the contest demonstrates that he visited Rome when not a part of any Mytilenean diplomatic mission. Even though Potamon did not win the position of Tiberius' tutor, the Mytilenean rhetorician sagaciously cultivated a lasting relationship with the future emperor. After seizing power in the empire, Tiberius gave Potamon, returning to his homeland, a letter of safe conduct in which he threatened war against anyone who would harm the rhetorician. ${ }^{71}$ Since the letter must have been written after $14 \mathrm{AD}$, Potamon must have lived to a ripe old age.

Potamon frequently visited Rome; however, quite unlike Theophanes, he appears to have remained very involved in the local political life in Mytilene. Surviving inscriptions stress his contributions to disseminating some imperial cults on Lesbos, such as the cult of Roma and, subsequently, Augustus. The circumstances of establishing the cult of Augustus were presented above. At this point, suffice it to say that Mytilene in $26 \mathrm{BC}$ decided to establish the cult of Augustus, organise competitions in the emperor's honour, make monthly sacrifices on the anniversary of his birthday and, perhaps, build him a temple..$^{72}$ In $29 \mathrm{BC}$, the cult of the goddess Roma and deified Caesar was officially permitted in the province of Asia, with a dedicated temple built in Pergamon. Other local cities, including Mytilene, also sought to bring the cult to their lands and began to petition Rome for permits. ${ }^{73}$ Significantly, establishing this cult in the city required appointing an archpriest: in Mytilene's case, his name does not appear in the relevant decree, but the mass of circumstantial evidence indicates that this office was also held by Potamon.

First, priests of the imperial and ruler cults in the Eastern Mediterranean often passed their position to their descendants: in this case, we know that Potamon's son, Gaius Claudius Diaphenes, became an archpriest of Roma and Caesar Augustus as Olympian Zeus, holding this office for his entire life. ${ }^{74}$ Second, Potamon is recorded to have made a dedication to Augustus, which he probably made as an archpriest of the imperial cult. ${ }^{75}$ Third, a surviving honorific decree records that Potamon honoured the Lesbian koinon. Its text indicates that Potamon was appointed priest of all deities and cults, presumably including him holding the office of the archpriest of the Augustan cult. ${ }^{76}$ Finally, Potamon in his capacity as the agonothetes (organiser of local games) procured wild animals,

70 Suda T 3; Cichorius 1888, 63; Parker 1991, 117.

$71 \quad$ Suda $\mathrm{P} 2127$.

72 Parker 1991, 119.

73 Price 1984, 250.

$74 I G$ XII, 2.656; Labarre 1996a, 288-289, no. 23. Augustus is mentioned as pater patros tas patridos, holding this title from $2 \mathrm{BC}$ until his death. If we assume that Potamon died ca AD 10, then this inscription should be dated to AD 10-14.

${ }^{75} I G \mathrm{XII}, 2.154$. The full name of the office held by Potamon has not survived. Only the phrase ho dia $b$ has survived, possibly a remnant of the formula ho dia biou, i.e. a life-long priest or archpriest.

76 IG XII, Suppl. 7; Labarre 1996a, 287-286, no. 22. 
such as bears, and imported them to Mytilene: spectacles involving hunting and fighting wild animals were usually presided over by priests of the imperial cult. ${ }^{77}$ Considering the evidence gathered above, we conclude that Potamon took an active interest in Mytilenean religious affairs, assisted in establishing the imperial cult in Mytilene and, most probably, held the archpriest office of the imperial cult until the end of his life, to be succeeded by his son and successive descendants. ${ }^{78}$

\section{BIBLIOGRAPHY}

Accame, S. (1946), Il dominio Romano in Grecia dalla guerra Acaica ad Augusto, Roma.

Anastasiadis, V. I. (1995), Theophanes and Mytilene's Freedom Reconsidered, Tekmeria 1: 1-13.

Anderson, W. S. (1963), Pompey, His Friends, and the Literature of the First Century B. C., BerkeleyLos Angeles.

Arangio-Ruiz, V. (1942), Senatusconsulta de Silaniana de Mytilensibus, RivFil 70: 125-130.

Badian, E. (1958), Foreign Clientelae 264-70, Oxford.

Bowersock, G. W. (1965), Augustus and the Greek World, Oxford.

Bowersock, G. W. (1969), Greek Sophists in the Roman Empire, Oxford.

Buraselis, K. (2001), Two Notes on Theophanes' Descendants, in: O. Salomies (ed.), The Greek East in Roman Context: Proceedings of a Colloquium Organised by the Finnish Institut at Athens (May 21 and 22, 1999), Helsinki: 61-70.

Chapot, V. (1904), La province romaine proconsulaire d'Asie, Paris.

Cichorius, C. (1888), Rom und Mytilene, Leipzig.

Dimopoulou-Piliouni, A. (2010), Communiquer avec la pouvoir romain: les lettres de Jules César publiées par la cité de Mytilène, Revue Internationale des droits de l'Antiquité 57 : 33-49.

Feissel, D. (2012), Inscriptions of Early Byzantinum and the Continuity of Ancient Onomastics, in: J. Davies, J. Wilkes (eds.), Epigraphy and the Historical Sciences, Oxford: 1-15.

Ferrary, J. L. (1988), Philhellénisme et impérialisme : aspects idéologiques de la conquête romaine du monde hellénistique, de la seconde querre de Macédoine à la guerre contre Mithridate, Rome.

Ferrary, J. L. (1990), Traités et domination romaine dans le monde hellénique, in: L. Canfora, M. Liverani, C. Zaccagnini (eds.), I trattati nel mondo antico. Forma, Ideologia, Funzione, Roma: 217-235.

Fishwick, D. (1987), The Imperial Cult in the Latin West, vol. I, Leiden.

Fournier, J. (2010), Entre Tutelle Romaine et Autonomie Locale. L'administration judiciaire dans les provinces hellénophones de l'empire romain (129 av. J.-C.-235 apr. J.-C.), Athènes.

Glucker, J. (1978), Antiochus and the Late Academy, Gottingen 1978.

Gold, B. K. (1985), Pompey and Theophanes of Mytilene, AJPh 106: 312-327.

Green, P. (1984), Lesbos and the Cities of Asia Minor, Austin.

Jones, A. H. M. (1971), The Cities of the Eastern Roman Provinces, 2nd ed., Oxford.

Labarre, G. (1996a), Les cités de Lesbos aux époques hellénistique et impériale, Lyon.

Labarre, G. (1996b), Théophane et l'octroi de la liberté à Mytilène: question de méthode, Tekmeria 2: $44-54$

Laqueur, R. (1934), s.v. Theophanes, RE V A.2, Stuttgart.

77 IG XII, Suppl. 9; Labarre 1996a, 112-113.

78 Parker 1991, 119-121 (121-129 a discussion of the activity of Potamon's descendants); Labarre 1996a, 124-125; Roddaz 2005, 407-408. 
Leach, J. (1978), Pompey the Great, London.

Parker, R. W. (1991), Potamon of Mytilene and His Family, ZPE 85: 115-129.

Pearson, L. (1960), The Lost Histories of Alexander the Great, Philadelphia.

Price, S. R. F. (1984), Rituals of Power: The Roman Imperial Cult in Asia Minor, Cambridge.

Rawson, E. (1985), Intellectual Life in the Late Roman Republic, London.

Robert, L. (1969), Théophane de Mytilène à Constantinople, CRAI 66: 42-64 (= id. Opera minora selecta, vol. V, Amsterdam 1989: 561-583).

Roddaz, J.-M. (2005), Marcus Agrippa, Rome.

Rowe G. (2002), Princes and Political Cultures. The New Tiberian Senatorial Decrees, Ann Arbor.

Salzmann, D. (1985), Cn. Pompeius Theophanes. Ein Benennungsvorschlag zu einem Porträt in Mytilene, $M D A I(\mathrm{R})$ 92: 245-260.

Santangelo, F. (2007), Sulla, the Elites and the Empire: A Study of Roman Policies in Italy and the Greek East, Leiden-Boston.

Seager, R. (1979), Pompey: A Political Biography, Oxford.

Sevin, F. (1743), Recherches sur la vie et les ouvrages de Théophane, Histoire de l'Académie des Inscriptions et Belles Lettres 14: 145-153.

Sherk, R. K. (1963a), Caesar and Mytilene, GRBS 4: 145-153.

Sherk, R. K. (1963b), Senatusconsultum de agris Mytilenaeorum, GRBS 4: 217-230.

Sherk, R. K. (1969), Roman Documents from the Greek East: Senatus consulta and epistulae to the Age of Augustus, Baltimore.

Sherwin-White, A. N. (1984), Roman Foreign Policy in the East 168 B. C. to A. D. 1, London. 